\title{
PERBEDAAN POLA KONSUMSI DAN ASUPAN ZAT GIZI ANAK STUNTING DAN TIDAK STUNTING USIA 12 - 23 BULAN
}

\author{
${ }^{1}$ Samuel, ${ }^{2}$ Hertanto W. Subagio, \& ${ }^{3}$ Suhartono \\ ${ }^{1}$ Dosen Poltekkes Kemenkes Tasikmalaya, ${ }^{2,3}$ Dosen Universitas Diponegoro
}

\begin{abstract}
Abstrak
Prevalensi stunting pada anak cenderung meningkat, baik tingkat nasional dan beberapa kabupaten/kota. Stunting yang terjadi pada usia di bawah dua tahun (baduta) akan berdampak pada gangguan pertumbuhan dan perkembangan sel otak. Tujuan penelitian untuk menganalisis perbedaan pola konsumsi dan asupan zat gizi energi, protein, vitamin C, kalsium dan phosphor. Desain penelitian cross sectional, subjek penelitian anak usia 12-23 bulan, yang lahir dengan berat badan normal, berjumlah 90 orang. Status stunting diperoleh dari data, panjang badan menurut umur, rerata asupan dari data recall 1×24 jam selama 2 hari berselang. Analisis data menggunakan uji independent $t$-test dan mann-whitney test dengan signifikansi $p<0,05$. Hasil penelitian; menunjukkan pola konsumsi anak tidak stunting lebih lengkap daripada anak stunting. Ada perbedaan asupan energi $(p=0,015)$ rerata asupan energi anak stunting lebih rendah 313,6 kilo. Asupan protein $(p=0,001)$ anak stunting lebih rendah $10,8 \mathrm{~g}$ dari tidak stunting. Vitamin $C(p=0,047)$, kalsium $(p=0,001)$ dan fosfor $(p=0,002)$, menunjukan adanya perbedaan. Anak tidak stunting susunan menunya lebih lengkap dari anak stunting. Ada perbedaan asupan energi, protein, vitamin $\mathrm{C}$, kalsium dan fosfor antara anak stunting dan tidak stunting.
\end{abstract}

Kata kunci ; Stunting, pola konsumsi, asupan zat gizi.

\section{Abstract}

The aim of research to analyze the differences in consumption patterns and nutrient intake of energy, protein, vitamin C, calcium, and phosphorus. Study Cross-sectional design, the study subjects children aged 12-23 months, were born with normal weight, totaling 90 people.status, stunting data obtained from the body length according to age, the mean intake of the data recall $1 \times 24$ hours for 2 days later. Data analysis used independent $t$-test and Mann-Whitney test with a significance of $p<0.05$. Research result; consumption patterns show nochildren stunting fuller of child stunting. There are differences in energy intake $(p=0.015)$ mean energy intake child stunting lower 313.6 kilo calories. Protein intake $(p=0.001)$ children stunting lower $10,8 \mathrm{~g}$ of no stunting. Vitamin $C(p=0.047)$, calcium $(p=0.001)$ and phosphorus $(p=0.002)$, indicating the differences. The child is normal arrangement fuller menu of child stunting. There are differences in the intake of energy, protein, vitamin $C$, calcium and phosphorus between child stunting and normal.

Keywords; Stunting, consumption patterns, nutrient intake.

\section{PENDAHULUAN}

Stunting adalah gejala yang paling sering digunakan sebagai proksi untuk kekurangan gizi kronis (Reinhardt, 2014). Dampak dari kekurangan gizi kronis terhambatnya pertumbuhan linier, dimana tubuh merespon kekurangan gizi tersebut dengan pemanfaatan zat gizi yang minimal sehingga terjadi perubahan patologis yang berdampak pada gangguan pertumbuhan. Proses ini dapat berlangsung selama priode pertumbuhan manusia, mulai dari masa 
konsepsi, masa balita, anak dan remaja (Sudiman, 2008).

Permasalahan stunting yang terjadi selama periode dibawah usia dua tahun (baduta), sangat menentukan tumbuh kembang selanjutnya (Escamilla at al ,2013; Strang,2011). Periode ini sistem syaraf pusat berkembang dengan sangat cepat (Avinashi at al, 2014). Anak baduta yang memiliki status gizi baik, akan mengalami perkembangan sel otak mencapai $80 \%$ dari perkembangan otak dewasa.(Palupi at al, 2013). Pemenuhan kecukupan zat gizi dalam periode ini sangat penting untuk memaksimalkan perkembangan otak anak (Georgieff, 2015).

Gangguan pertumbuhan linier atau stunting berakar dari masalah kemiskinan, serta faktor-faktor yang saling berhubungan, seperti asupan zat gizi, infeksi dan sosial ekonomi termasuk didalamnya budaya (Richard, 2012). Hasil survei Riset Kesehatan Dasar (Riskesdas) menunjukkan bahwa prevalensi stunting pada balita mengalami peningkatan, dari $35,6 \%$ (2010) menjadi $37,2 \%$ (2013) atau meningkat sebesar 1,6\% (Kemenkes, 2013).

Berdasarkan latar belakang tersebut, penelitian ini mengkaji apakah ada perbedaan pola konsumsi dan asupan zat gizi, makro dan mikronutrien pada anak stunting dan tidak stunting usia 12-23 bulan.

\section{METODE PENELITIAN}

Studi dilakukan di Kecamatan Sususkanlebak Kabupaten Cirebon dengan desain cross sectional. Penelitian ini dilakukan pada bulan Desember 2015 sampai dengan Januari 2016. Jumlah sampel sebesar 90 anak usia 12-23 bulan yang lahir dengan berat badan normal, artinya anak dengan riwayat Berat Badan Lahir Rendah (BBLR) dieksklusi dari penelitian. Tahapan pemilihan sampel pada gambar 1.

Gambar 1. Skema pemilihan sampel

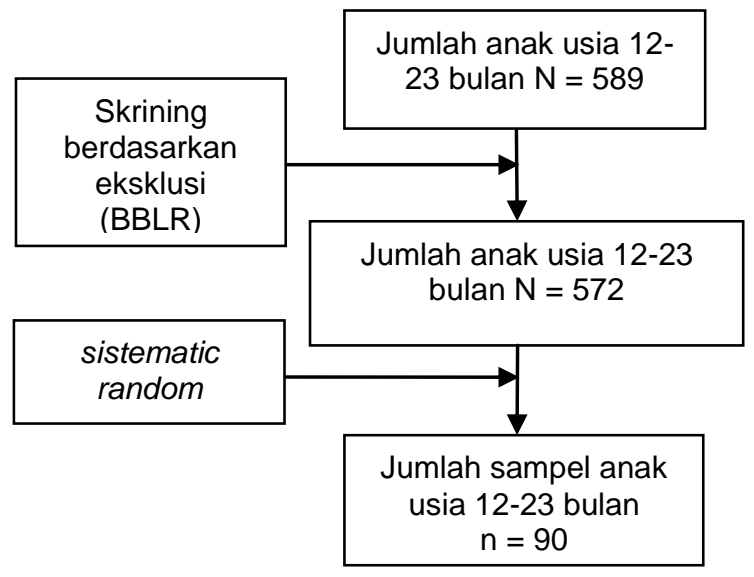

\section{HASIL PENELITIAN}

Permasalahan stunting

Gambar 2 kurva pertumbuhan anak, menunjukkan perbandingan pertumbuhan berdasarkan indeks Berat Badan menurut Panjang Badan (BB/PB) dan Panjang Badan menurut Umur (PB/U). Hasil penelitian adanya pergeseran kurva pertumbuhan ke arah minus dari nilai z-score, baik indeks BB/PB maupun indeks PB/U, dari 90 anak yang menjadi subjek penelitian, 33,3\% dikategorikan stunting. Hasil ini tidak jauh berbeda dengan Riskesdas tahun 2013 yang menunjukan prevalensi stunting sebesar 37,2\% (Kemenkes, 2013).

Gambar 2. Kurva Pertumbuhan Anak usia 12-23 bulan
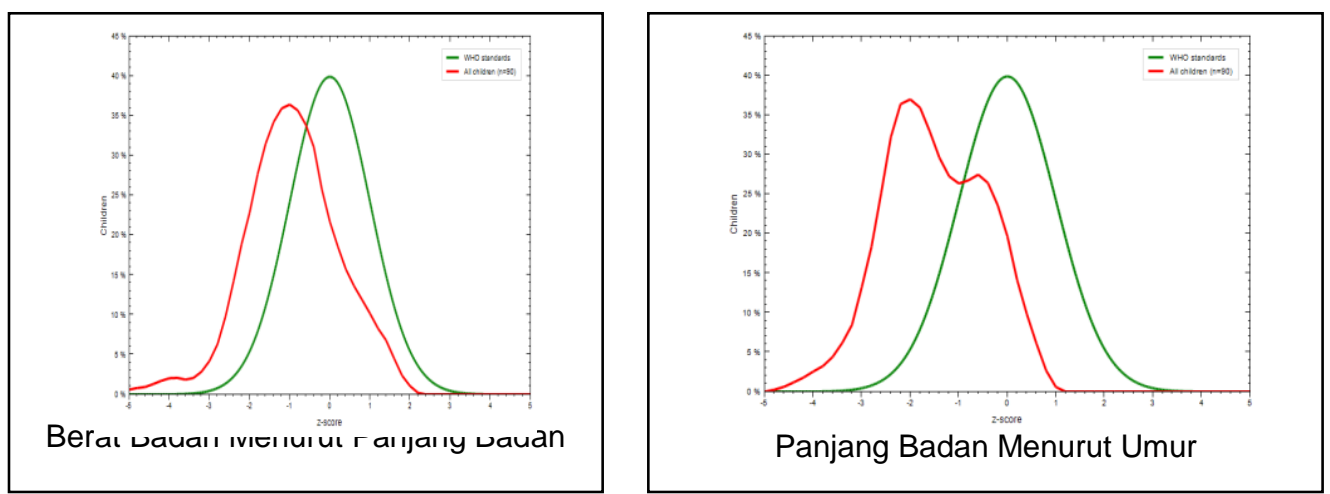
Tabel 1. Karateristik Subjek Penelitian

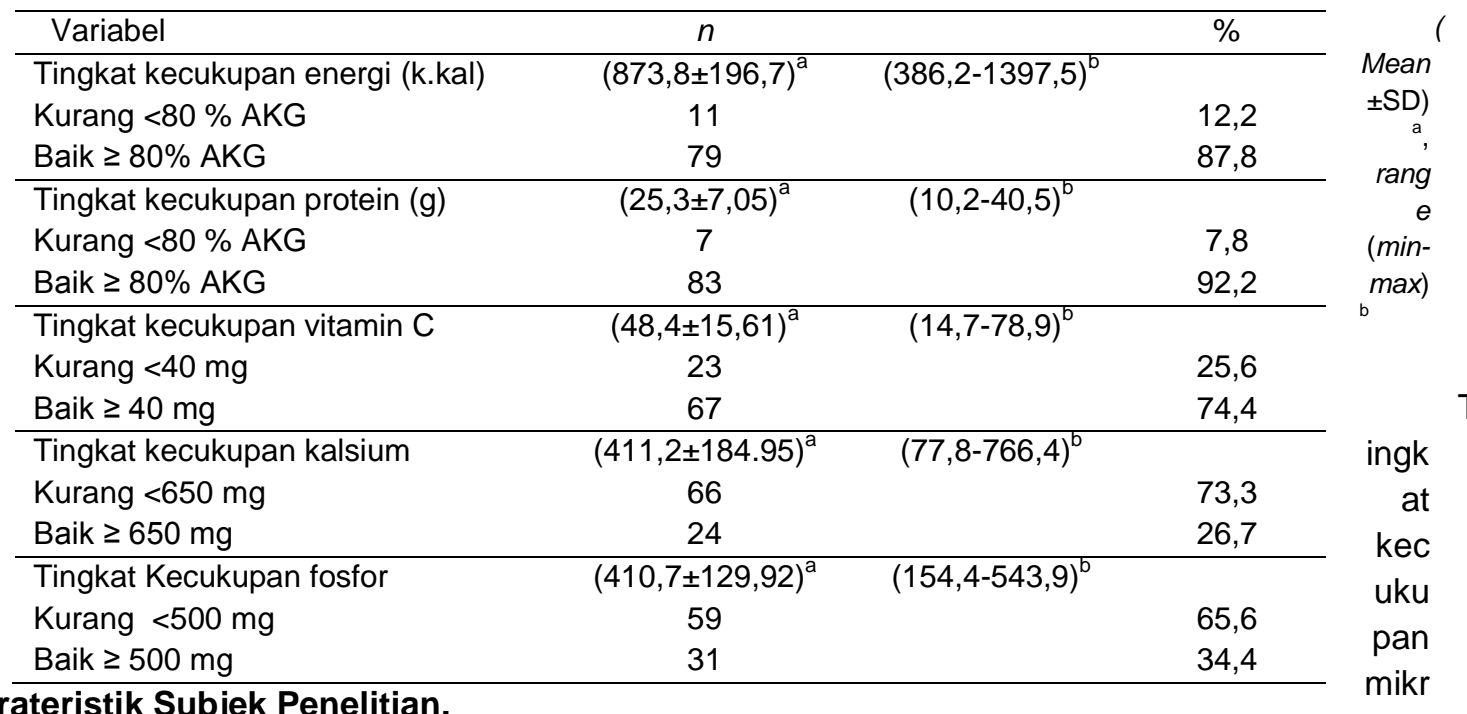

\section{Karateristik Subjek Penelitian.}

Tabel 1. Karateristik subjek penelitian dilihat dari tingkat kecukupan zat gizi makro dan mikro, yang diperoleh melalui recall $1 \mathrm{x}$ 24 jam, selama 2 hari berselang. Hasilnya menunjukkan rerata asupan energi sebesar 873,8 kkal. perhari dan sebanyak $12,2 \%$ anak dengan asupan energi kurang dari Angka Kecukupan Gizi (AKG), demikian juga dengan tingkat kecukupan protein, rerata asupan protein sebesar $25,3 \mathrm{~g}$ per hari dan sebanyak 7,8\% anak dengan asupan protein kurang dari AKG. onutrien seperti vitamin dan mineral hasilnya menunjukkan, rerata asupan vitamin C sebesar $48,42 \mathrm{~g}$ per hari dan $25,6 \%$ anak dengan asupan vitamin $\mathrm{C}$ kurang dari AKG. Rerata asupan kalsium dan fosfor, hasilnya menunjukkan, kalsium sebesar 411,16 mg per hari serta $73,3 \%$ anak dengan asupan kalsium kurang dari AKG, untuk rerata asupan fosfor sebesar $410,68 \mathrm{mg}$ per hari dan $65,6 \%$ anak dengan asupan kurang dari AKG.

Tabel 2. Pemberian ASI dan susunan menu makanan

\begin{tabular}{lcc}
\hline \multicolumn{1}{c}{ Praktik Pemberian Makan } & Stunting & Tidak Stunting \\
\cline { 2 - 3 } & $\mathrm{n}(\%)$ & $\mathrm{n}(\%)$ \\
\hline Pemberian ASI & $16(24,6)$ & $49(75,4)$ \\
\hline $\begin{array}{l}\text { ASI } \\
\text { Tidak ASI }\end{array}$ & $14(56,0)$ & $11(44,0)$ \\
\begin{tabular}{l} 
Susunan Menu Makanan \\
\hline $\begin{array}{l}\text { Makanan pokok, lauk hewani, lauk nabati, } \\
\text { sayur, buah }\end{array}$
\end{tabular} & $33(73,3)$ \\
$\quad \begin{array}{l}\text { Makanan pokok, lauk hewani, lauk nabati, } \\
\text { sayur/buah }\end{array}$ & $12(26,7)$ & $7(70,0)$ \\
$\begin{array}{l}\text { Makanan pokok, lauk hewani/lauk nabati, sayur, } \\
\text { buah }\end{array}$ & $3(30,0)$ & $13(61,9)$ \\
$\begin{array}{l}\text { Makanan pokok, lauk hewani/lauk nabati, } \\
\text { sayur/buah } \\
\quad \text { Makan pokok, lauk nabati/ sayuran }\end{array}$ & $8(38,1)$ & $5(55,6)$ \\
& $4(44,4)$ & $2(40,0)$ \\
\hline
\end{tabular}


Tabel 3. Rerata asupan zat gizi anak stunting dan tidak stunting usia 12-23 bulan

\begin{tabular}{|c|c|c|c|}
\hline Asupan Zat Gizi & $\begin{array}{c}\text { Stunting } \\
\text { Median } \pm S D\end{array}$ & $\begin{array}{c}\text { Tidak Stunting } \\
\text { Median } \pm S D\end{array}$ & Nilai $p$ \\
\hline \multicolumn{4}{|l|}{ Makronutrien } \\
\hline Energi (k.kal.) ${ }^{a}$ & $755,9 \pm 156,5$ & $1089,6 \pm 232,4$ & $0,015^{*}$ \\
\hline Protein $(\mathrm{g})^{\mathrm{a}}$ & $19,7 \pm 5,82$ & $31,3 \pm 9,3$ & $0,001^{*}$ \\
\hline \multicolumn{4}{|l|}{ Mikronutrien } \\
\hline $\operatorname{Vitamin} \mathrm{C}(\mathrm{mg})^{\mathrm{a}}$ & $39,8 \pm 11,5$ & $53,5 \pm 18,3$ & $0,047^{*}$ \\
\hline Kalsium $(\mathrm{mg})^{\mathrm{b}}$ & $280,2 \pm 148,5$ & $400,9 \pm 181,09$ & $0,001^{*}$ \\
\hline Fosfor $(\mathrm{mg})^{\mathrm{b}}$ & $318,2 \pm 118,11$ & $473,3 \pm 133,52$ & $0,002^{*}$ \\
\hline
\end{tabular}

\section{Pola konsumsi}

Tabel 2, gambaran pola konsumsi anak yang terdiri dari praktik pemberian ASI dan susunan menu pada kelompok stunting dan tidak stunting. Hasilnya menunjukkan persentase usia pemberian ASI pada kelompok stunting lebih rendah dari kelompok tidak stunting, yang dapat diartikan bahwa usia penyapihan pada kelompok stunting lebih cepat atau kurang dari dua tahun. Susunan menu, pada kolompok stunting, susunannya kurang beragam dibandingkan dengan kelompok tidak stunting, yang artinya susunan menu pada kelompok tidak stunting lebih lengkap daripada kelompok stunting.

\section{Rerata asupan zat gizi.}

Pada Tabel 3, hasil penelitian menunjukkan adanya perbedaan rerata asupan zat gizi makro, dimana asupan energi kelompok stunting lebih rendah 313,6 kilo kalori (k.kal.) dari kelompok tidak stunting. Hasil ini diperkuat dengan uji statistik yang menunjukkan adanya perbedaan signifikan antara kedua kelompok. Begitu pula rerata asupan protein pada kelompok stunting lebih rendah $10,8 \mathrm{~g}$ dari kelompok tidak stunting, hasil uji independent $t$-test menunjukkan adanya perbedaan yang signifikan.

Vitamin C dan mineral seperti kalsium dan fosfor merupakan zat gizi yang penting dalam proses pembentukan tulang. Hasil penelitian ini menunjukkan asupan vitamin $\mathrm{C}$ kelompok stunting lebih rendah 14,2 mg dari kelompok tidak stunting. Uji independent $t$ test terbukti adanya perbedaan yang signifikan asupan vitamin C, antara kelompok stunting dan kelompok tidak stunting. Rerata asupan kalsium dan fosfor pada kelompok stunting lebih rendah dari kelompok tidak stunting, masing-masing sebesar 120,9 mg dan $155 \mathrm{mg}$, berdasarkan hasil uji mann-whitney menunjukkan perbedaan yang signifikan.

\section{PEMBAHASAN}

Hasil penelitian menunjukkan kebiasaan makan atau pola konsumsi anak tidak stunting lebih lengkap dari anak stunting. Sejalan dengan penelitian di Kabupaten Gresik tahun 2012, yang menunjukkan bahwa anak tidak stunting susunan hidangannya lebih lengkap dari anak stunting (Welasasih, 2012). Kebiasaan makan sangat penting karena erat hubungannya dengan keadaan gizi, terutama kualitas dan kuantitas makanan yang dikonsumsi. Keragaman jenis pangan yang dikonsumsi akan mempengaruhi kualitas dan kelengkapan zat gizi, semakin beragam maka kualitas dan kelengkapan zat gizi akan memenuhi kebutuhan (Kemenkes, 2014).

Penelitian ini menunjukkan adanya perbedaan rerata asupan zat gizi makro, baik energi dan protein yang signifikan. Hal ini sejalan dengan penelitian Yuliana dan Sidarta, yang menunjukan adanya hubungan antara tingkat kecukupan energi dan protein dengan gangguan pertumbuhan (Yuliana, 2014). Energi dan protein sangat erat hubungannya, bila asupan energi tidak mencukupi kebutuhan untuk mempertahankan metabolisme, maka 
pemenuhan kecukupan energi diperoleh dari cadangan lemak dan glikogen otot. Selanjutnya jika berlangsung dalam waktu lama maka akan terjadinya katabolisme protein, guna memenuhi kebutuhan energi. Dampak yang ditimbulkan dari asupan energi yang kurang, yaitu terjadinya gangguan pertumbuhan pada anak. (Briend, 2015)

Selain energi dan protein, beberapa vitamin dan mineral yang sangat penting dalam proses pertumbuhan anak (Hoeft, 2012). Vitamin C merupakan salah satu vitamin yang diperlukan untuk pertumbuhan. Vitamin C berperan dalam sintesis kolagen yang merupakan bahan utama jaringan konektif pada tulang (Avinashi, 2014). Penelitian ini menunjukan adanya perbedaan yang signifikan asupan vitamin $\mathrm{C}$ antara anak stunting dan tidak stunting, Sejalan dengan hasil penelitian di Kairo tahun 2013, menunjukkan adanya perbedaan tingkat kecukupan vitamin C antara anak stunting dengan anak tidak stunting (Wafai, 2013).

Mineral utama yang diperlukan dalam proses pembentukan tulang adalah kalsium dan fosfor. Kekurangan kedua mineral tersebut dapat menghambat proses pertumbuhan (Avinashi, 2014). Hasil uji statistik menunjukkan adanya perbedaan yang signifikan asupan kalsium dan asupan fosfor pada anak stunting dan tidak stunting. Hasil ini diperkuat dengan penelitian di Mesir yang menyatakan bahwa ada perbedaan tingkat kecukupan kalsium dan fosfor antara anak stunting dan yang tidak stunting (Wafai, 2013).

\section{KESIMPULAN}

Ada perbedaan susunan menu antara anak stunting dan tidak stunting, dimana anak tidak stunting menunya lebih beragam. Selain itu ada perbedaan asupan zat gizi makro energi dan protein serta asupan zat gizi mikro seperti vitamin $\mathrm{C}$, kalsium dan fosfor antara anak stunting dan tidak stunting.

\section{DAFTAR PUSTAKA}

Avinashi A, Secker D, Zlotkin S. (2014) Buku ajar ilmu gizi. Penerbit Buku Kedokteran. 4th ed. Jakarta;

Briend A, Khara T, Dolan C. (2015) Wasting and stunting similarities and differences:Policy and programmatic implications, Food and Nutrition Bulletin

Escamilla RP. Post-1000 days growth trajectories and child cognitive development in low- and middleincome countries. Am J Clin Nutr. 2013

Georgieff M K. Nutrition and the developing brain: nutrient priorities and measurement. Am J Clin Nutr 2015

Hoeft B, Weber P, Eggersdorfer M. (2012) Micronutrients a global perspective on asupan, health benefits and economics. Int. J. Vitam. Nutr.

Kemenkes RI, (2013) Riset Kesehatan Dasar. Badan Penelitian dan Pengembangan Kesehatan. Jakarta

Kemenkes RI, 2014 Pedoman Gizi Seimbang, Jakarta Dirjen Bina Gizi dan Kesehatan Ibu dan Anak Direktur Bina Gizi;

Palupi E, Sulaeman A, Ploeger A.(2013) World hunger, malnutrition and brain development of children. Journal on Food,

Agriculture and Societ

Reinhardt K, Fanzo J. (2014) Addressing chronic malnutrition through multisectoral, sustainable approaches: a review of the causes and consequences. Frontiers in Nutrition and Environmental Sustainability

Sudiman H. (2008) Stunting atau pendek awal perubahan patologis atau adaptasi karena perubahan sosial ekonomi yang berkepanjangan. Media litbang kesehatan

Wafai Z.A, Mikhail, Hassan M, Sobhy, Hanaa H, El-sayed, et al. (2013) Effect of nutritional status on growth pattern of stunted preschool children in Egypt. Acad. J. Nutr.

Welasasih BD, Wirjatmadi B. (2012) Beberapa Faktor yang Berhubungan dengan Status Gizi Balita Stunting. The Indonesian Journal of Public Health.

Yuliana, Sidiartha IGL. (2014) Association between energy and macronutrients asupan with anthropometric indicators in children.2014: MEDICINA.

Richard SA, Black RE, Checkley W. Revisiting the relationship of weight and 
height in early childhood. Adv. Nutr. 2012. 